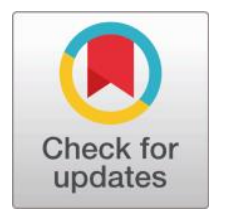

Article Type: Research Paper

\title{
Determinants of Investment Decisions in the Capital Market During the COVID-19 Pandemic
}

\author{
Erni Suryandari Fathmaningrum* and Tiyas Puji Utami
}

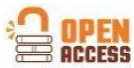

\section{AFFILIATION:}

Department of Accounting, Faculty of Economics and Business, Universitas Muhammadiyah Yogyakarta, Special Region of Yogyakarta, Indonesia

\section{*CORRESPONDENCE: \\ erni@umy.ac.id}

DOI: 10.18196/jai.v23i1.13408

\section{CITATION:}

Fathmaningrum, E. S., \& Utami, T. P. (2022). Determinants of Investment Decisions in the Capital Market During the COVID-19 Pandemic. Journal of Accounting and Investment, 23(1), 147-169.

\section{ARTICLE HISTORY}

Received:

17 Dec 2021

Revised:

01 Jan 2022

Accepted:

19 Jan 2022

\section{cc) (i) $\odot$}

This work is licensed under a Creative Commons Attribution-NonCommercialNoDerivatives 4.0 International License

\section{JAI Website:}

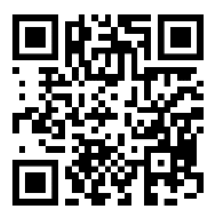

\begin{abstract}
:
Research aims: This study aims to determine the effect of herding behavior, accounting information, and information technology on investment decisions through investment interest during the COVID-19 pandemic.

Design/Methodology/Approach: Using the purposive sampling method, this study used a sample of investors who had just invested in the Indonesian capital market during the COVID-19 pandemic. This quantitative study employed primary data based on questionnaires distributed to respondents via the internet. Respondents in this study were 241 investors. Hypothesis testing in this study utilized SEM-PLS analysis through the SMART PLS 3.0 application.

Research findings: The results showed that herding behavior did not affect investment decisions through investment interest in the capital market during the COVID-19 pandemic. Meanwhile, accounting information and technology information influenced investment decisions through investment interest in the capital market during the COVID-19 pandemic.

Theoretical contribution/Originality: The study results contribute to the literature (body of knowledge), especially as additional discussion toward theory and literature related to herding behavior, accounting information, and information technology on investors decisions through investment interest to invest in the capital market, which is still very limited.
\end{abstract}

Keywords: Herding behavior; Accounting information; Information technology; Investment interest; Investment decision; Capital market

\section{Introduction}

In 2020, the world was shocked by the emergence of Corona Virus Disease 2019 (COVID-19) that has caused changes in all community activities, including activities in the capital market. This situation has significantly impacted Indonesia and made the Jakarta Composite Index (JCl) fluctuate (Muklis, 2016). It is evidenced by data showing that stock indexes in various countries, such as the Nasdaq and Dow Jones Industrial Average (DJIA), the Nikkei 225 in Japan, the Hang Seng Index in Hong Kong, Shanghai in China, the FTSE 100 Index in London, and the DAX Index in Germany, have been reported by various mass media to be volatile during the COVID-19 phase (Junaedi \& Salistia, 2020). 
In Indonesia itself, COVID-19 was first announced on March 2, 2020, a pandemic. After being declared a pandemic, the $\mathrm{JCl}$ trend declined and closed to the level of 5,361 (Kusnandar \& Bintari, 2020). It was recorded until December 2020 in Indonesia that the $\mathrm{JCl}$ movement experienced its lowest point in March as the beginning of the month after Indonesia was first confirmed to have reported COVID-19. However, quoted from the Indonesia Stock Exchange (IDX) page, during the COVID-19 pandemic, the frequency of daily transactions in the capital market reached a record high, which was 619 thousand times as of November 30, 2020. On December 30, 2020, the Indonesia Stock Exchange (IDX) held a press release, stating that during 2020, the number of investors increased $56 \%$ from 2.48 million to 3.87 million investors, consisting of stock, bond, and mutual fund investors. According to Town (2020), in his research, investing during the COVID-19 pandemic was the right decision because many people sold their shares, which caused the stock price to be cheap. However, investors must also make adjustments, one of which is by being careful in choosing a holistic and diverse investment portfolio since the stock market in various countries has decreased (Ngwakwe, 2020).

The high enthusiasm and increasing number of investors in the capital market during the COVID-19 pandemic occurred because they were influenced by several factors in practice, including accounting information and psychological factors in making investment decisions (Latief \& Niu, 2020). In terms of its form and content, accounting information can strongly influence the investment decision-making process (Hartono, 2008). The concept of accounting information used in making investment decisions emphasizes "how financial statements can be more useful?" It means that accounting information in financial statements must provide useful value to its users in terms of decision making so that the content of accounting information is an important consideration in the investment decision-making process; thus, it can be said that accounting information is useful for investors (Puspitaningtyas, 2012). Research on the importance of accounting information for potential investors and investors was pioneered by Baker and Haslem (1973) and provided the result that an investor needs different information to analyze their instruments in the capital market; it can happen since it may be that each investor needs different information. Good information to support investment decisions is needed because if investors do not get good information, they risk investment returns from their wealth (Kartini \& Nugraha, 2015). Decisions are taken based on irrational considerations so that the results are also irrational (Komala \& Kartini, 2017).

Furthermore, accounting information is related to market value and contains information obtained from the company's financial statements through fundamental analysis techniques (Puspitaningtyas, 2012). Fundamental analysis is a technique carried out to provide benefits for the relationship between accounting information and market values and is expected to provide benefits for investors in estimating the expected rate of return and risk from stock investments in making investment decisions (Puspitaningtyas, 2012). The investment decision in question is buying, selling, or maintaining share ownership.

Research on the effect of accounting information on investment decisions has been conducted previously, such as research carried out by Akbar et al. (2016), Rakhmatulloh and Haryono (2019), and Somathilake (2020), which stated that accounting information 
did not affect investment decision making, and investors did not pay attention to fundamental analysis. In contrast to research conducted by Obaidat (2016) and Latief and $\mathrm{Niu}$ (2020), it is asserted that accounting information influenced investment decisions.

Next is the psychological factor. The psychological factor in question is the possibility that an investor's investment decision-making is influenced by cognitive and emotional factors (Umboh \& Atahau, 2019). It is also explained in behavioral finance theory that in making financial decisions, an individual may be influenced by psychological factors. Behavioral finance is a psychological and social science theory regarding the human side in decisionmaking (Prosad et al., 2015). If investors have involved psychological or emotional factors in deciding to invest, it will cause investors not to think rationally (Komala \& Kartini, 2017).

As described by Alquraan et al. (2016), investors' psychological behavior that influences their decisions is divided into risk perception, herding, loss averse, and belief. During the COVID-19 pandemic, financial behavior that may influence investment decisions is herding behavior because this behavior is the investor's behavior influenced by cognitive factors and follows other investors in making investment decisions (Setiawan et al., 2018). Research on the influence of herding behavior on investment decisions has been carried out by Vijaya (2014) and Putri and Isbanah (2020). However, in contrast to research conducted by Alquraan et al. (2016) and Setiawan et al. (2018), herding behavior did not affect investment decisions, where investors tended to receive information and conduct analysis before buying shares and did not have a tendency to follow the noise in the market.

Furthermore, technological developments also significantly influence the capital market (Negara \& Febrianto, 2020). As a facility provider, the Indonesia Stock Exchange (IDX) provides convenience for investors and potential investors to invest in the capital market. In addition, the Financial Services Authority (OJK) is tasked with overseeing the rapid development of various investment transaction platforms. Investment trends among the public are also supported by many public figures who provide information about the investment. All investment information can be accessed online through various internet platforms (Ummah et al., 2021).

Research on information technology has also been conducted several times. As explained by Ummah et al. (2021), information technology is increasingly advanced and provides convenience, affecting investment decisions. However, in studies carried out by Amalia et al. (2020) and Cahya and Setyarini (2020), information technology did not affect investment decisions.

Based on the inconsistent results of previous studies, the researchers added the investment interest variable as an intervening variable between the independent variable and the dependent variable as the novelty of this study. Investment interest itself is defined as a desire for an object that causes him to carry out activities (Khairani, 2017). As an intervening variable, investment interest is supported by the theory of planned behavior, suggesting that a person's interest will be an intermediary for factors that have a certain impact (Tandio \& Widanaputra, 2016). Ajzen (1991) also explained that desires 
could influence the emergence of behavior; it indicates that the higher the individual's desire, the higher the probability of it happening. The higher a person desires to make an investment or interest in investing, the higher he is to make investment decisions.

Moreover, previous research on investment interest is still little done. The results obtained by Umboh and Atahau (2019) and Zaniarti et al. (2017) stated that herding behavior variables could affect investment interest. In addition, Kasmir (2013) and Hasanaj and Kuqi (2019) revealed that accounting information influenced investment interest. Also, Negara and Febrianto (2020) affirmed that the advancement of information technology affected investment interest in the capital market. Information technology also impacted the process of buying and selling securities.

Thus, this research provides practical benefits for stakeholders, especially in making investment policies in the capital market, and for investors to be more careful and look at accounting information in making decisions. In addition, this study also contributes to the literature, particularly as an additional discussion of the determinants of investment decisions in the capital market, including herding behavior, accounting information, and information technology, which are still very limited.

\section{Literature Review and Hypotheses Development}

\section{Theory of Planned Behavior}

The theory of planned behavior is an enhanced theory of reasoned action, with the addition of the perceived behavioral control variable. As in the theory of reasoned action, the primary focus in this theory is that individual intentions can influence someone to do something. Ajzen (1991) further explained that a person's intention is assumed to be a desire that influences the emergence of behavior; it indicates that the higher the individual's desire, the higher the probability of it happening. Furthermore, explained by Triwijayanti and Koesworo in Situmorang et al. (2014), the desire to do something is influenced by a specific desire to behave.

In the theory of planned behavior, it is explained that humans act according to intentions, influenced by behavior, subjective norms, and behavioral control (Tandio \& Widanaputra, 2016). Ajzen (1991) also stated three dimensions of the relationship between intention and behavior: attitude towards the behavior, subjective norm, and perceived behavioral control.

The relationship between this theory and this research is that during the COVID-19 pandemic, a person has a positive attitude towards investing in the capital market (attitude towards the behavior), supported by an environment that can influence him to invest (subjective norm), and the ease of accessing or investing (perceived behavioral control); thus, investors will have higher intentions and ultimately invest in the capital market. It is supported by Situmorang et al. (2014) statement that investors will seek 
various information about investing in the capital market if they have the intention or interest.

\section{Utility Theory}

Tversky and Kahneman (1981) explained utility theory as a decision with risks and goals to get maximum results. This theory assumes that individuals who make decisions are rational, but often, decision-makers are not rational when making their choices. Neumann and Morgenstern, who proposed utility theory, argue that in making investment decisions, investors already have the knowledge, information, confidence, and skills regarding the analysis of investment opportunities and consequences (Pradhana, 2018).

In this theory, it is described that individuals who make decisions are considered to have a rational nature, but often, in determining their decisions, individuals are not rational. It can be concluded that utility theory studies how investors avoid risk. Based on this utility concept, each individual action aims to maximize the amount of utility to achieve satisfaction (Puspitaningtyas, 2012). In this case, accounting information is included in the actions of investors to avoid risk and get maximum wealth (Sumtoro \& Anastasia, 2015).

\section{Behavioral Finance}

Kahneman and Tversky (1979) asserted that human behavior in making decisions is based on psychological factors; making a risky decision can be interpreted as a choice or gamble. This behavior is called financial behavior. Behavioral finance is an approach that explains how humans make investments or activities related to finance, influenced by psychological factors (Sumtoro \& Anastasia, 2015). Studies on behavioral finance have shown that cognitive and emotional factors influence rational behavior in investment decisions. Thus, the herding behavior research variable is one of behavioral finance since herding is a situation when rational people start behaving irrationally by following other people's judgments when making decisions that can lead to mistakes (Simões Vieira \& Valente Pereira et al., 2015).

\section{Herding Behavior and Investment Interest}

The theory of planned behavior explains that one dimension of the relationships between the determinants of intention and behavior is subjective norms. Subjective norms elucidate that, before the COVID-19 pandemic, perhaps, someone did not believe in investing, who then invested after seeing friends or other people invest and get a profit. It is relevant to herding behavior, which is the behavior of investors who follow other investors (Setiawan et al., 2018).

Herding behavior is also part of behavioral finance and includes irrational behavior that does not base its decisions on information or the company's fundamental values. The emergence of herding behavior is because the benefits offered are an attraction or interest for investors, according to Umboh and Atahau (2019). Furthermore, according to Nandar et al. (2018), one of the factors for the occurrence of interest is the environment 
or scope in accordance with the wishes or needs. Therefore, it is relevant to the state of the COVID-19 pandemic. The higher the level of herding behavior, the higher the interest in investing.

The effect of herding behavior on investment interest has been studied by Umboh and Atahau (2019) and Zaniarti et al. (2013), revealing that herding behavior positively affected investment interest with student investors respondents at eight campuses in North Sulawesi Province, Indonesia.

$\boldsymbol{H}_{1}$ : Herding behavior positively influences the investment interest in the capital market during the COVID-19 pandemic.

\section{Accounting Information and Investment Interest}

Accounting information is the output of accounting, divided into two general categories: financial accounting information and management accounting information. The accounting information used includes reports, stock valuations, expected profits of the company, and the current stock exchange, to be analyzed to get a profit on the funds that have been invested (Efendi, 2015). Under utility theory studying how investors avoid risk, each individual action aims to maximize the amount of utility to achieve satisfaction (Puspitaningtyas, 2012).

From the explanation above, investors will use accounting information to perform fundamental analysis of the company to get maximum profit or return. In this regard, accounting information is very much needed in the economic situation caused by the COVID-19 pandemic. The COVID-19 pandemic has caused investors to be more careful in choosing companies to use accounting information to choose the appropriate company. The better the accounting information provided, the more interested investors are in investing in the company.

Previous research conducted by Kasmir (2013) and Hasanaj and Kuqi (2019) asserted that the better the company's productivity is presented in accounting information, the more attractive the company is to investors and will be more attractive to investors.

$\boldsymbol{H}_{2}$ : Accounting information has a positive effect on investment interest in the capital market during the COVID-19 pandemic.

\section{Information Technology and Investment Interest}

Advances in information technology have now grown far and facilitated all human affairs. In investment, all needs regarding investment information can be accessed through information technology. In addition, the government continues to promote and educate the public about investment and the capital market using information technology, for example, the program of "Yuk Nabung Saham" [Let us Save Shares]. 
In this case, social media is an advancement in information technology that makes it easier for humans to communicate. The government has also penetrated social media to educate the public. Many social media provide information and training or online seminars to the public. For companies themselves, information technology is a vital strategy to compete in the business world (Mastura et al., 2020). Following the theory of planned behavior regarding the context of perceived behavior control, investors have obtained information through increasingly sophisticated technology to provide convenience, knowledge, and insight so that investment interest is higher.

In addition, many conveniences are obtained from advances in information technology; according to research by Negara and Febrianto (2020), technological advances affected investment interest since they impacted the ease of making the investment process. In line with the research of Ummah et al. (2021), Isticharoh and Kardoyo (2020), and Cahya and Kusuma (2019), information technology influenced investment interest.

$\boldsymbol{H}_{3}$ : Information technology has a positive effect on investment interest in the capital market during the COVID-19 pandemic.

\section{Investment Interest and Investment Decisions}

An investment decision is to invest in one or more assets to gain future profits (Hartono \& Wahyuni, 2017). Meanwhile, investment interest is a desire for an object and causes the person to carry out activities regarding investment (Khairani, 2017). These activities are like finding out about different types of investments, taking the time to learn about them, and encouraging the person to make an investment decision or give it a try. It is also under the theory of planned behavior.

In connection with the COVID-19 situation, many people are experiencing economic and financial problems, which causes people to be more careful. It can be concluded that society desires to improve its situation and causes a person to carry out investment activities. Thus, the higher the public interest, the more influential it will be on investment decisions during the COVID-19 pandemic.

Investment interest influenced investment decisions, as researched by Sulistyowati (2017), Sakdiyah et al. (2018), and Ummah et al. (2021). If someone is interested in investing, it will encourage him to take investment decisions.

$\boldsymbol{H}_{4}$ : Investment interest has a positive effect on investment decisions in the capital market during the COVID-19 pandemic.

\section{Herding Behavior and Investment Decisions}

Investors are considered rational if investment decisions are made based on consideration of the risks and rewards obtained (Alquraan et al., 2016). However, 
according to behavioral finance, cognitive and emotional factors can influence investors in making investment decisions, and one of them is herding behavior. Liem (2017) explained that herding behavior is the follow-up behavior of an investor in making decisions for various reasons. The influence of the people around can lead to the emergence of herding behavior. Someone with herding behavior will be easily influenced by the decisions of others (Gozalie \& Anastasia, 2015). The higher the level of herding, the higher the level of investment decisions (Putri \& Isbanah, 2020). During the COVID-19 pandemic, there has been an increase in the number of investors on the Indonesia Stock Exchange (IDX). Public awareness about investment continues to soar, and 2020 is the peak when people decide to invest in the capital market. Investing has then become like a trend followed by many people. This situation encourages other investors to follow the decision of most investors in investing. Thus, the more investors who join to start investing, the higher the investment decision in the capital market.

Studies on herding behavior have been carried out by Vijaya (2014) and Putri and Isbanah (2020), finding that herding behavior affected investment decisions. Their sample data used investors at the Investment Gallery in Surabaya City by distributing questionnaires.

$\boldsymbol{H}_{5}$ : Herding behavior has a positive effect on investment decisions in the capital market during the COVID-19 pandemic.

\section{Accounting Information and Investment Decisions}

Accounting information is used by investors to assess the company's fundamentals, analyze the company's prospects in the future, and calculate the company's profitability (Rakhmatulloh \& Haryono, 2019). In accordance with utility theory, accounting information is employed to avoid risk and maximize profits (Tversky \& Kahneman, 1981). If an investor has high accounting information, he will increasingly analyze the company's prospects in the future for investment decision-making (Sumtoro \& Anastasia, 2015). In a state of the COVID-19 pandemic, investors must have appropriate and adequate information in making investment decisions since the capital market during a pandemic will be highly volatile due to unstable conditions.

Research on accounting information has been carried out by several previous researchers, such as Bashir (2013), who studied finance students, bankers, and teachers in Pakistan. According to his research, accounting information affected investment decisions. It is supported by Obaidat (2016), who researched Amman Stock Exchange (ASE) investors in Jordan and Latief and Niu (2020), who researched PT. MNC Sekuritas Manado investors.

$\boldsymbol{H}_{6}$ : Accounting information has a positive effect on investment decisions in the capital market during the COVID-19 pandemic. 


\section{Information Technology and Investment Decisions}

Advances in information technology provide comfort and convenience to humans. Information technology provides information quickly, such as capital market developments and stock price movements to companies that need funds on the stock exchange. Technological advances are also used by companies to become a competitive strategy in the market. Online trading provided by the company encourages people to make investment decisions easier (Cahya \& Setyarini, 2020). Therefore, it can be concluded that the more advanced information technology, the more it will encourage investment decision-making. It is in line with the explanation in the theory of planned behavior regarding the context of perceived behavioral control. Prospective investors have obtained information through increasingly sophisticated technology to provide convenience, knowledge, and insight, resulting in more potential investors making investments. Information technology has been studied by previous researchers, such as Ummah et al. (2021) and Amalia et al. (2020), stating that information technology influenced investment decisions with the ease and convenience provided.

$H_{7}$ : Information technology has a positive effect on investment decisions in the capital market during the COVID-19 pandemic.

\section{Investment Interest as Intervening}

Ajzen (1991) suggested that a person's desire or interest would be the intermediary of factors with a high probability of occurrence. Another factor, in this case, is the psychological factor, which has a big role in determining decision-making (Sumtoro \& Anastasia, 2015). Here, herding or investor behavior that tends to follow the majority of other investors might influence investors' actions during the COVID-19 pandemic due to environmental conditions and the increasing number of investors in Indonesia.

It is reinforced by research conducted by Umboh and Atahau (2019) that herding behavior affected investment interest and Sakdiyah et al. (2018) that interest influenced investment decisions.

$\boldsymbol{H}_{\mathbf{8}}$ : Herding behavior has a positive effect on investment decisions in the capital market through investment interest during the COVID-19 pandemic.

Furthermore, the theory of planned behavior explains that someone who wants to do something will begin with an interest or desire. Someone with an investment interest will find out about a type of investment, ranging from advantages, disadvantages, investment performance, and others (Situmorang et al., 2014), and spend more time studying it (Ajzen, 1991). In this case, accounting information is a factor with an impact on potential investors to invest in the capital market during the COVID-19 pandemic, with their interests or desires as intermediaries. 
Accounting information is also utilized by investors to assess the company's fundamentals and prospects in the future. If individuals have more accounting information through investors' investment interests, they are more likely to make investment decisions. This statement is reinforced by research conducted by Latief and Niu (2020), Obaidat (2016), and Sakdiyah et al. (2018), stating that accounting information is used for fundamental analysis that affects investment decisions.

$\boldsymbol{H}_{9}:$ Accounting information affects investment decisions in the capital market through investment interest during the COVID-19 pandemic.

In addition, advances in information technology provide convenience and comfort for investors to invest. The benefits of information technology not only make it easier for investors to get information easily but are also used by companies to become a vital strategy to compete in the market. The government also continues to provide information on the capital market and investment through information technology with the "Yuk Nabung Saham" program to the public. The amount of information provided and the existing campaigns will lead to someone interested in investing. Under the theory of planned behavior, what is related to the determinants of interest is the individual's perception of whether it is easy to realize a behavior, and information technology provides convenience in investing in the capital market. To invest, someone will have characteristics, such as how much effort they put into finding out about a type of investment, ranging from advantages, weaknesses, investment performance, and others (Situmorang et al., 2014). Investors will also use existing information technology to continue to explore information. Thus, the role of information technology has an influence on investment decisions through investment interest, supported by research by Isticharoh and Kardoyo (2020), Negara and Febrianto (2020), Ummah et al. (2021), Cahya and Kusuma (2019), and Sakdiyah et al. (2018).

$\boldsymbol{H}_{10}$ : Information technology has a positive effect on investment decisions in the capital market through investment interest during the COVID-19 pandemic.

Based on the hypotheses developed, this study formulated a research model, as shown in Figure 1.

\section{Research Method}

This quantitative research used a questionnaire instrument distributed online to investors who had just started investing in the Indonesian capital market during the COVID-19 pandemic. Due to a large number of investors, the researchers employed a purposive sampling technique using the sample size according to Hair et al. (2010), namely the "10 times rule". The minimum sample must be 60 (6 x 10); this study used 241 samples and met these requirements. The criteria that had to be met by investors who were 
respondents in this study were investors who had started their investments during the COVID-19 pandemic, which included investing in stocks, mutual funds, and bonds.

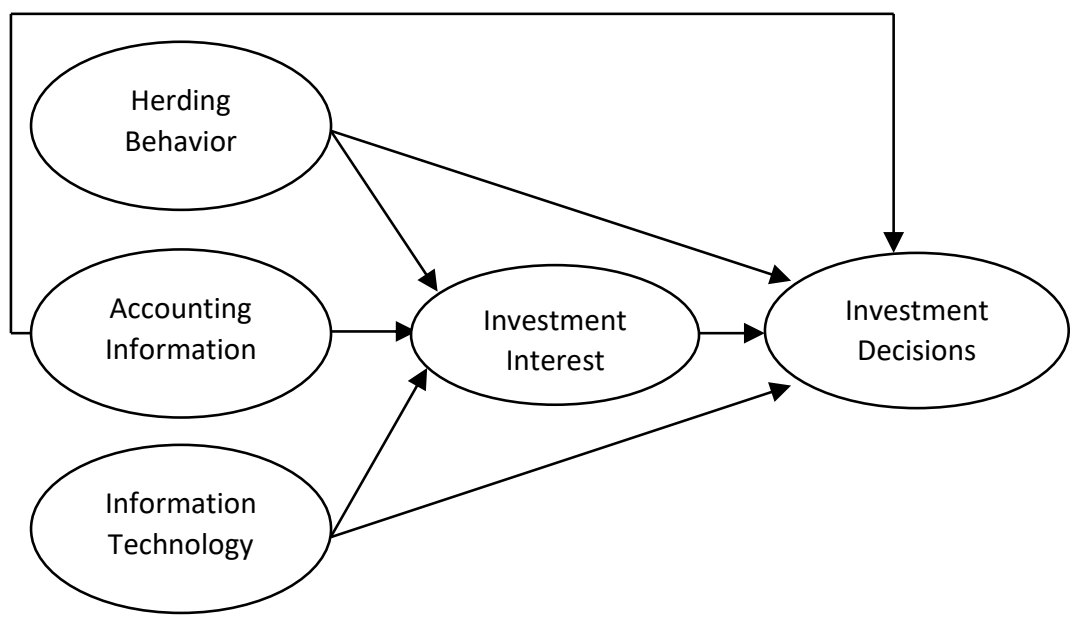

Figure 1 Research Model

The data used in this study consisted of primary data obtained directly from research respondents using a measuring instrument in the form of a questionnaire using a 5-point Liker scale: 1 indicating "strongly disagree" to 5 indicating "strongly agree". The instruments used were adapted from Khan (2017) for investment decisions, Situmorang et al. (2014) and Kotler and Keller (2009) for investment interest, Vijaya (2014) and Kudryavtsev et al. (2013) for herding behavior, Obaidat (2016) for accounting information and Suryani (2013) for information technology.

Before testing the hypothesis using Partial Least Square (PLS), the researchers tested the Common Method Variance (CMV) utilizing SPSS v22 to find out that the data used did not have the potential for bias or error, such as self-reported bias, complexity, ambiguity, and questionnaire scale format (Mackenzie \& Podsakoff, 2012). Furthermore, PLS is latent variable modeling used by several dependent constructs that have been used by many business and accounting studies (Sholihin \& Ratmono, 2015). The PLS approach is also suitable for this research since it requires a relatively small sample size and a weak theoretical basis (Chin et al., 2003). According to Hair et al. (2014), PLS requires stages consisting of (1) model specifications, (2) evaluation of external models, and (3) evaluation of the inner model.

\section{Result and Discussion}

\section{Instrument and Data Quality Test}

Using a questionnaire, this study used a sample of investors who have recently invested in the Indonesian capital market during the COVID-19 pandemic. The questionnaire was 
distributed through social media, such as WhatsApp, Twitter, telegram groups regarding mutual fund investment, and the highest gain was through Instagram @ngertisaham. The investments followed by respondents in the Indonesian capital market were stocks, mutual funds, and bonds.

Table 1 Outer Loading

\begin{tabular}{|c|c|c|c|}
\hline $\begin{array}{l}\text { Latent } \\
\text { Variable }\end{array}$ & Code & Indicators & $\begin{array}{l}\text { Outer } \\
\text { Loading }\end{array}$ \\
\hline \multirow{4}{*}{$\begin{array}{l}\text { Investment } \\
\text { Decisions }\end{array}$} & ID1 & Having knowledge about investment & 0.680 \\
\hline & ID2 & $\begin{array}{l}\text { Feeling safe to invest in the capital market because it is } \\
\text { under the supervision of the Financial Services Authority } \\
\text { (FSA) }\end{array}$ & 0.806 \\
\hline & ID3 & $\begin{array}{l}\text { Feeling safe to invest in the capital market because IDX is } \\
\text { the regulator }\end{array}$ & 0.867 \\
\hline & ID4 & $\begin{array}{l}\text { Feeling safe to invest in the capital market because it is } \\
\text { protected by law }\end{array}$ & 0.827 \\
\hline \multirow{4}{*}{$\begin{array}{l}\text { Investment } \\
\text { Interest }\end{array}$} & II1 & The desire to find out about the basics of investing & 0.804 \\
\hline & 112 & $\begin{array}{l}\text { The desire to find out about investments from other } \\
\text { figures }\end{array}$ & 0.721 \\
\hline & 113 & Taking the time to learn more about investing & 0.792 \\
\hline & 114 & Confidence & 0.565 \\
\hline \multirow{5}{*}{$\begin{array}{l}\text { Herding } \\
\text { Behavior }\end{array}$} & HB1 & Investment decisions are influenced by others. & 0.551 \\
\hline & HB2 & Investment decisions depend on other people's decisions. & 0.763 \\
\hline & HB3 & Reacting quickly to changes in other investors' decisions & 0.404 \\
\hline & HB4 & $\begin{array}{l}\text { Preferring to buy shares if the shares are in demand from } \\
\text { the start }\end{array}$ & 0.144 \\
\hline & HB5 & $\begin{array}{l}\text { If the volume of shares were higher in the market in the } \\
\text { last month, it would increase the number of stock market } \\
\text { holdings. }\end{array}$ & -0.404 \\
\hline \multirow{5}{*}{$\begin{array}{l}\text { Accounting } \\
\text { Information }\end{array}$} & Al1 & Previous profit & 0.833 \\
\hline & $\mathrm{Al} 2$ & Liquidity & 0.827 \\
\hline & $\mathrm{Al} 3$ & Stock price in the market & 0.784 \\
\hline & Al4 & Total assets & 0.848 \\
\hline & Al5 & Previous cash flow & 0.855 \\
\hline \multirow[t]{6}{*}{$\begin{array}{l}\text { Information } \\
\text { Technology }\end{array}$} & IT1 & $\begin{array}{l}\text { Using technology to get information quickly and } \\
\text { accurately }\end{array}$ & 0.890 \\
\hline & IT2 & Different types of mass media provide more information. & 0.901 \\
\hline & IT3 & Technology can help transact at any time. & 0.861 \\
\hline & IT4 & Online trading applications provide convenience. & 0.648 \\
\hline & IT5 & Facilitating consumer and company communication & 0.763 \\
\hline & IT6 & Fast and accurate service & 0.818 \\
\hline
\end{tabular}

Before testing the formulated hypothesis using PLS, the Common Method Variance (CMV) test was carried out utilizing the SPSS v.22 application to avoid the causes of errors in testing the data. From the CMV test, the results obtained were $34.602 \%$. It means that the tested data indicates that $\mathrm{CMV}$ did not occur in this study. Next, the researchers tested the hypothesis, starting with the outer model test. The outer model consists of validity and reliability tests. The validity test consists of convergent validity and discriminant validity. Convergent validity uses the outer loading value with each indicator showing a result of more than 0.5 (Table 1 ). 
From these results, according to Hair et al. (2006), indicators that did not meet the requirements of less than 0.5 were HB3, HB4, and HB5, so they had to be eliminated. Thus, the convergent validity results were met. Furthermore, in PLS, discriminant validity is typically assessed using the Fornell-Lacker criterion. In statistical terms, if the square root of AVE for constructs is higher than the correlations between it and any other construct in the model, discriminant validity is established (Fornell \& Larcker, 1981) (Table 2).

Table 2 Discriminant validity test results using Fornell-Lacker

\begin{tabular}{lccccc} 
& $\begin{array}{c}\text { Herding } \\
\text { Behavior }\end{array}$ & $\begin{array}{c}\text { Accounting } \\
\text { Information }\end{array}$ & $\begin{array}{c}\text { Investment } \\
\text { Decisions }\end{array}$ & $\begin{array}{c}\text { Investment } \\
\text { Interest }\end{array}$ & $\begin{array}{c}\text { Information } \\
\text { Technology }\end{array}$ \\
\hline $\begin{array}{l}\text { Herding Behavior } \\
\begin{array}{l}\text { Accounting } \\
\text { Information }\end{array}\end{array}$ & 0.878 & -0.207 & 0.830 & & \\
$\begin{array}{l}\text { Investment } \\
\text { Decisions } \\
\text { Investment }\end{array}$ & -0.280 & 0.516 & 0.798 & & \\
$\begin{array}{l}\text { Interest } \\
\text { Information }\end{array}$ & -0.092 & 0.406 & 0.506 & 0.726 & \\
Technology & -0.266 & 0.544 & 0.736 & 0.519 & 0.818 \\
\hline
\end{tabular}

As shown in Table 3, the AVE values of all constructs were higher than their highest crosscorrelation. It can be concluded that discriminant validity was also fulfilled (Gefen \& Straub, 2005). In addition, the value of Cronbach's Alpha for each construct was more than 0.6 , and the value of composite reliability for all constructs showed results in accordance with the rule of thumb, as shown in Table 3 (Chin et al., 2003; Fornell \& Larcker, 1981). Thus, it can be concluded that all constructs had met the criteria of validity and reliability, and then testing for hypotheses could be done.

Table 3 Cronbach's Alpha, Composite Reliability, and AVE

\begin{tabular}{lccc} 
& Cronbach's Alpha & Composite Reliability & AVE \\
\hline Herding behavior & 0.728 & 0.870 & 0.771 \\
Accounting Information & 0.887 & 0.917 & 0.689 \\
Investment Decisions & 0.806 & 0.875 & 0.637 \\
Investment Interest & 0.701 & 0.815 & 0.528 \\
Information Technology & 0.899 & 0.923 & 0.669 \\
\hline
\end{tabular}

The summary of the results of hypothesis testing is presented in Table 4. These results show that herding behavior did not influence investment interest or investment decisions. Meanwhile, accounting information and information technology positively influence investors' investment interests and investment decisions during the COVID-19 pandemic.

Furthermore, this study revealed that investment interest could intervene in the relationship between accounting information and information technology on investment decisions in the capital market during the COVID-19 pandemic. Meanwhile, the herding behavior variable did not have an influence either directly or through investment interest on investors' investment decisions. 
Table 4 Hypothesis Results

\begin{tabular}{|c|c|c|c|c|c|}
\hline \multicolumn{2}{|c|}{ Hypothesis } & Original Sample(0) & t-statistic & p-values & Conclusion \\
\hline $\mathrm{HB}->\mathrm{II}$ & $\mathrm{H}_{1}$ & 0.061 & 1.039 & 0.150 & Not Supported \\
\hline $\mathrm{Al}->\mathrm{II}$ & $\mathrm{H}_{2}$ & 0.175 & 2.117 & 0.017 & Supported \\
\hline IT $->$ II & $\mathrm{H}_{3}$ & 0.444 & 5.449 & 0.000 & Supported \\
\hline II -> ID & $\mathrm{H}_{4}$ & 0.154 & 2.718 & 0.003 & Supported \\
\hline$H B->I D$ & $\mathrm{H}_{5}$ & 0.066 & 1.470 & 0.067 & Not Supported \\
\hline $\mathrm{Al}->\mathrm{ID}$ & $\mathrm{H}_{6}$ & 0.128 & 2.201 & 0.014 & Supported \\
\hline IT -> KI & $\mathrm{H}_{7}$ & 0.562 & 8.006 & 0.000 & Supported \\
\hline$H B \rightarrow I I->I D$ & $\mathrm{H}_{8}$ & 0.009 & 0.960 & 0.169 & Not Supported \\
\hline $\mathrm{Al}->\| I->I D$ & $\mathrm{H}_{9}$ & 0.027 & 1.656 & 0.049 & Supported \\
\hline IT -> II -> ID & $\mathrm{H}_{10}$ & 0.068 & 2.271 & 0.012 & Supported \\
\hline
\end{tabular}

HB: Herding Behavior; Al: Accounting Information; IT: Information Technology; II: Investment Interest; ID: Investment Decisions

\section{The Influence of Herding Behavior on Investment Interest in the Capital Market During the COVID-19 Pandemic}

Based on the research results above, herding behavior did not affect investment interest in the capital market during the COVID-19 pandemic. Research on herding behavior on investment interest in the capital market has also been carried out by Umboh and Atahau (2019) and Zaniarti et al. (2013), showing that herding behavior positively affected investment interest. In contrast to previous research conducted by Umboh and Atahau (2019), only conducted for student investors at the IDX Investment Gallery in eight campuses in North Sulawesi Province, this research developed into investors who invest during the COVID-19 pandemic, which is spreading throughout Indonesia.

Furthermore, research on herding behavior on investment interest is still difficult to find. Related to this, the theory of planned behavior states that the environment can affect a person's interest, but from the hypothesis testing results, it can be concluded that investors had a desire to invest by finding their information and analyzing the information obtained without environmental influences, who had high enthusiasm for following the market (Situmorang et al., 2014).

The Influence of Accounting Information on Investment Interest in the Capital Market During the COVID-19 Pandemic

In this study, accounting information positively affected investment interest in the capital market during the COVID-19 pandemic. Research on the effect of accounting information on investors' investment interest in the capital market is still little done, and literature on this matter is still difficult to find. Meanwhile, accounting information has an essential role in starting to invest in the capital market. Under utility theory, information is used to avoid risk and get the maximum benefit in the future. Accounting information is the basis for an investor to assess the company's fundamentals, especially during a pandemic like this. From the results of testing this research hypothesis, during the COVID-19 pandemic, investors are still very concerned about accounting information published by companies or the Indonesia Stock Exchange (IDX). In accordance with research carried out by Kasmir (2013), the better the productivity of the company presented in accounting information, 
the more attractive the company is to investors and the more attractive it will be for investors. It is also reinforced by Hasanaj and Kuqi (2019), stating that accounting information in financial statements is influential in attracting investors to invest. The better the financial statements presented, the higher the investment interest.

\section{The Influence of Information Technology on Investment Interest in the Capital Market During the COVID-19 Pandemic}

Based on the theory of planned behavior, one of the factors that can lead to a desire is the perceived behavioral control of easy or difficult, which makes a certain behavior in each individual (Ajzen, 1991). The context in this research is that information technology will make it easier for investors to invest in the capital market with the help of an internet connection. The government also supports it with the "Yuk Nabung Saham" program, which invites the public to invest in the capital market (Negara \& Febrianto, 2020). Unlimited technological advances also provide space for potential publics, which may influence sharing information and experiences on the internet about investing in the capital market. Thus, it can encourage public investment interest to start investing in the capital market (Ummah et al., 2021).

During the COVID-19 pandemic, a positive signal in the ease of obtaining information and making investments will also increase investment interest in the capital market. The easier it is for people to access and obtain information, the higher the interest in investing in the capital market during the COVID-19 pandemic. This research aligns with studies conducted by Negara and Febrianto (2020), Cahya and Kusuma (2019), Isticharoh and Kardoyo (2020) and Ummah et al. (2021), who found that information technology had a positive effect on investment interest in the capital market. Also, supported by Sukirno's (2011) opinion, one of the factors that can determine the level of interest in investing in the capital market is information technology.

\section{The Influence of Investment Interest on Investment Decisions in the Capital Market During the COVID-19 Pandemic}

In this study, investment interest positively affected investment decisions in the capital market during the COVID-19 pandemic. It is in accordance with the theory of planned behavior that in doing something, someone begins with interest (Ajzen, 1991). During the COVID-19 pandemic, people are also still experiencing economic and financial difficulties, so without realizing it, people desire to improve their economic situation by being more careful in using their money. In addition, people use this pandemic period as a good strategy to start investing in the capital market. It is supported by Town (2020) statement that the pandemic period is the right moment to start investing since many investors are selling their portfolios.

This research is in line with research conducted by Sulistyowati (2017), Sakdiyah et al. (2018), and Ummah et al. (2021). Furthermore, the results of this study extend the results of previous studies, most of which examined the effect of investment interest on 
investment decisions in students. The results of this study also tested investment interest in investors who had just invested in the capital market during the COVID-19 pandemic.

\section{The Influence of Herding Behavior on Investment Decisions in the Capital Market During the COVID-19 Pandemic}

From the research results obtained, Indonesian investors were not influenced by herding behavior in making investment decisions. It indicates that in making investment decisions in the capital market during the COVID-19 pandemic, investors are not affected by the investment decisions of other investors. Meanwhile, according to Zaniarti et al. (2013), the attitude of herding is easy to influence novice investors to change their stance when in an urgent situation. In this regard, the COVID-19 pandemic can be an urgent situation since it causes financial problems. However, maybe because of the urgency of investors to invest and not have herding behavior, investors will be more careful in investing their money in the capital market because of this pandemic.

This research is supported by previous research conducted by Alquraan et al. (2016) and Setiawan et al. (2018). A study by Alquraan et al. (2016) examined the herding behavior of individual investors in Saudi Arabia and stated that individual investors in Saudi Arabia still paid attention to fundamental analysis in decision making.

The Influence of Accounting Information on Investment Decisions in the Capital Market During the COVID-19 Pandemic

Utility theory proposes that accounting information is used to avoid risk and get the maximum benefit (Sumtoro \& Anastasia, 2015). The results of this study align with the theory that investors who made investment decisions during the COVID-19 pandemic used existing accounting information to avoid risk in a volatile market.

This study is also in line with research conducted by Bashir (2013), which examined finance students, bankers, and teachers in Pakistan. According to his research, accounting information impacted investment decisions. It is supported by Obaidat (2016), who researched Amman Stock Exchange (ASE) investors in Jordan and Latief and Niu (2020), who examined investors of PT MNC Sekuritas Manado. Also, another researcher, such as Al Sawalqa (2012), also researching in Jordan, found that the accounting information contained in the annual financial statements is the most important and vital source of information for investment decisions in the capital market. Moreover, these results agree with the research of Chen et al. (2001) and Angelovska (2014).

\section{The Influence of Information Technology on Investment Decisions in the Capital Market During the COVID-19 Pandemic}

Information technology positively affected investment decisions in the capital market during the COVID-19 pandemic in this study. Information technology makes it easy for investors to analyze and filter investment products in the capital market they want. Advances in information technology also help investors analyze through applications 
connected via the internet, and smartphones can be utilized (Ummah et al., 2021). In addition, the company uses technological advances to become a competitive strategy in the market. One of them is online trading provided by the company, which will encourage investors to make investment decisions easier (Cahya \& Setyarini, 2020). It is also reinforced by the theory of planned behavior, stating that investors have obtained information through increasingly sophisticated information technology so that investment decisions in the capital market are also getting higher.

Moreover, this research supports the research conducted by Ummah et al. (2021) on the influence of information technology on investment decisions in the capital market for students at the Investment Gallery, Sunan Ampel State Islamic University Surabaya. This study also aligns with the research of Amalia et al. (2020) and Mastura et al. (2020).

\section{The Influence of Herding Behavior on Investment Decisions Through Investment Interest in the Capital Market During the COVID-19 Pandemic}

The results of this study uncovered that investment decisions during the COVID-19 pandemic were not influenced by subjective norms described in the theory of planned behavior. It means that investment interest could not mediate the relationship between psychological factors, namely herding and investment decisions. The state of the COVID19 pandemic causing the trend of investment to increase also did not provide incentives for investors to know information about investments not to cause investors to make investment decisions. Here, research on herding behavior is still very difficult to find.

The results of this study extend the findings of Zaniarti et al. (2017), who found that most novice investors will have high herding behavior because they may be able to change their stance, especially when under pressure. As in the COVID-19 pandemic, people are under financial pressure. Thus, most likely, they will go with the flow of their environment without any basis for further analysis. In addition, the current research is an extension of previous research with the result that, perhaps due to pressure during the COVID-19 pandemic, people will be more careful in investing their capital. However, their research is limited to investors in the IDX Investment Gallery with $A B$ Mitra Sinarmas Sekuritas Regional West Java, while this present study included Indonesian investors.

\section{The Influence of Accounting Information on Investment Decisions Through Investment Interest in the Capital Market During the COVID-19 Pandemic}

Accounting information positively affected investment decisions through investment interest in the capital market during the COVID-19 pandemic. From the point of view of the theory of planned behavior, everything begins with interest (Ajzen, 1991). When investors have an interest, investors will find out various information about investing in the capital market (Situmorang et al., 2014). Investment interest will mediate other factors, which have a more likely impact.

An investor will also use accounting information to analyze before deciding on an investment to reduce risk (Sumtoro \& Anastasia, 2015), and this statement is in line with 
utility theory. It supports research conducted by Latief and Niu (2020), Obaidat (2016), and Sakdiyah et al. (2018), stating that accounting information is used for fundamental analysis, which influences investment decisions through the desire or interest in investment.

\section{The Influence of Information Technology on Investment Decisions Through Investment Interest in the Capital Market During the COVID-19 Pandemic}

Information technology positively affected investment decisions through investment interest in the capital market during the COVID-19 pandemic. Here, the theory of planned behavior argues that doing everything begins with interest (Ajzen, 1991). Thus, it is explained that what is related to the determinant of interest is the individual's perception of whether it is easy to realize a behavior, and information technology intended in this study provides convenience for an investor in making investment decisions in the capital market. Someone interested in investing will make an effort to find information about the type of investment, advantages and disadvantages, investment performance until conducting investment analysis (Situmorang et al., 2014). Investors will also seek such information using advances in information technology; therefore, the easier access to the capital market using information technology will be, the higher the influence of investors to make investment decisions in the capital market.

This research agrees with previous studies carried out by Isticharoh and Kardoyo (2020), Negara and Febrianto (2020), Ummah et al. (2021), Cahya and Kusuma (2019), and Sakdiyah et al. (2018) regarding the influence of information technology on investment decisions through investment interest.

\section{Conclusion}

This study aims to obtain empirical evidence on the effect of herding behavior, accounting information, and information technology on investment decisions through investment interest in investors who have just started investing in the Indonesian capital market during the COVID-19 pandemic. Based on the test results, it is known that investment decisions in the Indonesian capital market during the COVID-19 pandemic were influenced by accounting information and information technology, both directly and through investment interest. Thus, it can be denoted that investors tend to be rational in making investment decisions by using accounting information as consideration and supported by the development of information technology to invest in the capital market. Meanwhile, the herding behavior variable, directly or indirectly through investment interest, showed no effect. Based on these results, it can be concluded that when investing in the capital market during the COVID-19 pandemic, investors were not influenced by psychological factors, and it supports the results of the explanation above that accounting information affected investment decisions.

The results of this study provide theoretical and practical implications. Theoretically, this research extends the findings regarding herding behavior and accounting information on 


\section{Fathmaningrum \& Utami}

Determinants of Investment Decisions in the Capital Market ...

investment interest in the capital market, contributing to academics and researchers by supporting the theory and results of previous research on the same topic. Practically, it is expected that in making investment decisions, investors are more careful and use accounting information as the basis for making decisions. To the stakeholders, it is recommended to improve the quality of services, especially the use of information technology in the capital market.

However, the limitations of this study are the limited literature on variables of herding behavior and accounting information on investment interest, and the researchers only focused on investors who have just started investing during the COVID-19 pandemic. The researcher's suggestion to further researchers is to add interview techniques to support their findings so that the research results are more accurate and increase the number of respondents so that they do not only focus on investors who are just starting to invest during the COVID-19 pandemic.

\section{References}

Ajzen, I. (1991). The theory of planned behavior. Organizational Behavior and Human Decision Processes, 50(2), 179-211. https://doi.org/10.1016/0749-5978(91)90020-t

Akbar, M., Salman, A., Mughal, K. S., Mehmood, F., Makarevic, N., \& Campus, I. (2016). Factors affecting the individual decision making: a case study of Islamabad Stock Exchange. European Journal of Economic Studies, 15(1), 242-258. https://doi.org/10.13187/es.2016.15.242

Al Sawalqa, F. (2012). Different sources of corporate financial information and investment decision opportunity: evidence from Amman Stock Exchange. International Journal of Business and Management, 7(7), 110-120. https://doi.org/10.5539/ijbm.v7n7p110

Alquraan, T., Alqisie, A., \& Al Shorafa, A. (2016). Do behavioral finance factors influence stock investment decisions of individual investors? (Evidences from Saudi Stock Market). American International Journal of Contemporary Research, 6(3), 159-169. Retrieved from http://www.aijcrnet.com/journals/Vol 6 No 3 June 2016/16.pdf

Amalia, N., Malikah, A., \& Mahsuni, A. W. (2020). Faktor-faktor yang mempengaruhi pengambilan keputusan pada investasi saham. Jurnal Ilmiah Riset Akuntansi, 9(1), 47-57. Retrieved from http://riset.unisma.ac.id/index.php/jra/article/view/7436

Angelovska, J. (2014). Determining the factors that influence investors' decisions to buy or sell stocks on the Macedonian Stock Market. Economic Development, 16(3), 137-151.

Baker, H. K., \& Haslem, J. (1973). Information needs of individual investors. Journal of Accountancy, 136, 64-90.

Bashir, T. (2013). An assessment study on the factors influencing the individual investor decision making behavior. IOSR Journal of Business and Management, 9(5), 37-44. https://doi.org/10.9790/487x-0953744

Cahya, A. D., \& Setyarini, E. (2020). Menguji keputusan berinvestasi dari perspektif pemblajaran pasar modal, kemajuan teknologi, uang saku mahasiswa dan bauran pemasaran (Galeri Investasi Bursa Efek Indonesia Fakultas Ekonomi UST). UPAJIW A DEW ANTARA: Jurnal Ekonomi, Bisnis dan Manajemen Daulat Rakyat, 4(1), 15-26. Retrieved from https://jurnal.ustjogja.ac.id/index.php/upajiwa/article/view/6857

Cahya, B. T., \& Kusuma, N. A. (2019). Pengaruh motivasi dan kemajuan teknologi terhadap minat investasi saham. Al-Masharif: Jurnal Ilmu Ekonomi dan Keislaman, 7, 192-207. 
Retrieved from http://jurnal.iain-padangsidimpuan.ac.id/index.php/Almasharif/article/view/2182

Chen, C. J. ., Chen, S., \& Su, X. (2001). Is accounting information value-relevant in the emerging Chinese stock market? Journal of International Accounting, Auditing and Taxation, 10(1), 1-22. https://doi.org/10.1016/s1061-9518(01)00033-7

Chin, W. W., Marcolin, B. L., \& Newsted, P. R. (2003). A Partial Least Squares latent variable modeling approach for measuring interaction effects: results from a Monte Carlo simulation study and an electronic-mail emotion/adoption study. Information Systems Research, 14(2), 189-217. https://doi.org/10.1287/isre.14.2.189.16018

Efendi, D. (2015). Pengaruh Informasi Akuntansi dan Ketidakpastian Tugas terhadap Kinerja Manajer. Journal of Accounting and Investment, 8(2), 137-146. Retrieved from https://journal.umy.ac.id/index.php/ai/article/view/633

Fornell, C., \& Larcker, D. F. (1981). Evaluating structural equation models with unobservable variables and measurement error. Journal of Marketing Research, 18(1), 3950. https://doi.org/10.2307/3151312

Gefen, D., \& Straub, D. (2005). A practical guide to factorial validity using pls-graph: tutorial and annotated example. Communications of the Association for Information Systems, 16, $91-$ 109. https://doi.org/10.17705/1 cais.01605

Gozalie, S. \& Anastasia, N. (2015) Pengaruh perilaku heuristics dan herding terhadap pengambilan keputusan investasi properti hunian. Finesta, 3(2), 28-32. Retrieved from https://publication.petra.ac.id/index.php/manajemen-keuangan/article/view/3576

Hair, J.F., Black, W.C., Babin, B.J., Anderson, R.E. \& Tatham, R.L. (2006). Multivariate data analysis. Vol. 6. Pearson Prentice Hall, Upper Saddle River.

Hartono, E. F. \& Wahyuni, D. U. (2017). Analisis faktor-faktor keputusan investasi pada perusahaan property dan real estate. Jurnal Ilmu dan Riset Manajemen, 6(6). Retrieved from http://jurnalmahasiswa.stiesia.ac.id/index.php/jirm/article/view/1648

Hartono, J. (2008). Teori Portofolio dan Analisis Investasi. $5^{\text {th }}$ Ed. Yogyakarta: BPFE.

Hasanaj, P., \& Kuqi, B. (2019). Analysis of financial statements. Humanities and Social Science Research, 2(2), 17-27. https://doi.org/10.30560/hssr.v2n2p17

Isticharoh, I., \& Kardoyo, K. (2020). Minat investasi diprediksi dari motivasi diri, pengetahuan investasi, dan teknologi media sosial. Economic Education Analysis Journal, 9(3), 892-906. Retrieved from https://journal.unnes.ac.id/sju/index.php/eeaj/article/view/42414

Junaedi, D., \& Salistia, F. (2020). Dampak pandemi Covid-19 terhadap pasar modal di Indonesia. Al-Kharaj: Jurnal Ekonomi, Kenangan \& Bisnis Syariah, 2(2), 109-131. https://doi.org/10.47467/alkharaj.v2i2.112

Kahneman, D., \& Tversky, A. (1979). Prospect theory: an analysis of decision under risk. Econometrica, 47(2), 263-291. https://doi.org/10.2307/1914185

Kartini, K., \& Nugraha, N. F. (2015). Pengaruh illusions of control, overconfidence dan emotion terhadap pengambilan keputusan investasi pada investor di Yogyakarta. Jurnal Inovasi dan Kewirausahaan, 4(2), 115-123. https://doi.org/10.20885/ajie.vol4.iss2.art6

Kasmir, K. (2013). Analisis laporan keuangan. Jakarta: Rajawali Pers.

Khairani, M. (2017). Psikologi Belajar. Yogyakarta: Aswaja Pressindo.

Khan, M. Z. U. (2017). Impact of availability bias and loss aversion bias on investment decisions making, moderating role of risk perception. Journal of Modern Developments in General Management \& Administration (IMP ACT: JMDGMA), 1(1), 17-28.

Komala, D. S., \& Kartini. (2017). Pengaruh availability bias, loss aversion bias, dan representativeness bias terbadap pengambilan keputusan investasi. Forum Manajemen Indonesia (FMI) Ke-9, 135.

Kotler, P., \& Keller, K. L. (2009). Manajemen pemasaran. Jakarta: Erlangga. 


\section{Fathmaningrum \& Utami}

Determinants of Investment Decisions in the Capital Market ...

Kudryavtsev, A., Cohen, G., \& Hon-Snir, S. (2013). "Rational" or "intuitive": are behavioral biases correlated across stock market investors? Contemporary Economics, 7(2), 31-53. https://doi.org/10.5709/ce.1897-9254.81

Kusnandar, D. L., \& Bintari, V. I. (2020). Perbandingan abnormal return saham sebelum dan sesudah perubahan waktu perdagangan selama pandemi Covid-19. Jurnal Pasar Modal dan Bisnis, 2(2), 195-202. https://doi.org/10.37194/jpmb.v2i2.49

Latief, N. F., \& Niu, F. A. L. (2020). Accounting Information and Psychological Factors in Capital Market: Do these Affect the Investors' Decisions to Invest? Jurnal Reviu Akuntansi dan Keuangan, 10(2), 335-348. https://doi.org/10.22219/jrak.v10i2.12931

Liem, W. K A. (2017). Perilaku herding pada indeks sektoral dan saham-saham terpilih. Thesis. Universitas Atma Jaya Yogyakarta.

MacKenzie, S. B., \& Podsakoff, P. M. (2012). Common method bias in marketing: causes, mechanisms, and procedural remedies. Journal of Retailing, 88(4), 542-555. https://doi.org/10.1016/i.jretai.2012.08.001

Mastura, A., Nuringwahyu, S., \& Zunaida, D. (2020). Pengaruh motivasi investasi, pengetahuan investasi dan teknologi informasi terhadap minat berinvestasi di pasar modal. JLAGABI (Jurnal Ilmu Administrasi Niaga/Bisnis), 9(1), 64-75. Retrieved from http://riset.unisma.ac.id/index.php/jiagabi/article/view/6125

Muklis, F. (2016). Perkembangan dan tantangan pasar modal Indonesia. Al Masraf (Jurnal Lembaga Keuangan dan Perbankan), 1(1), 1-12.

Nandar, H., Rokan, M. K., \& Ridwan, M. (2018). Faktor yang mempengaruhi minat mahasiswa berinvestasi di pasar modal syariah melalui galeri investasi IAIN Zawiyah Cot Kala Langsa. Kitabab: Jurnal Akuntansi dan Kenangan Syariah, 2(2), 179-205. Retrieved from http://jurnal.uinsu.ac.id/index.php/JAKS/article/view/4148

Negara, A. K., \& Febrianto, H. G. (2020). Pengaruh kemajuan teknologi informasi dan pengetahuan investasi terhadap minat investasi generasi milenial di pasar modal. Business Management Journal, 16(2), 81-95. https://doi.org/10.30813/bmj.v16i2.2360

Ngwakwe, C. (2020). Effect of COVID-19 pandemic on global stock market values: a differential analysis. CEconomica, 16(2), 255-269. Retrieved from https://dj.univdanubius.ro/index.php/AUDOE/article/view/258

Obaidat, A. (2016). The value relevance of accounting information in emerging stock exchange markets "case of Jordan." Research Journal of Finance and Accounting, 7(12), 184. https://iiste.org/Journals/index.php/RJFA/article/view/31530

Pradhana, R. W. (2018). Pengaruh financial literacy, cognitive bias, dan emotional bias terhadap keputusan investasi (studi pada investor galeri investasi Universitas Negeri Surabaya). Jurnal Ilmu Manajemen (IIM), 6(3), 108-117. Retrieved from https://jurnalmahasiswa.unesa.ac.id/index.php/jim/article/view/23849

Prosad, J. M., Kapoor, S., \& Sengupta, J. (2015). Theory of Behavioral Finance. Advances in Finance, Accounting, and Economics, 1-24. https://doi.org/10.4018/978-1-4666-74844.ch001

Puspitaningtyas, Z. (2012). Relevansi nilai informasi akuntansi dan manfaatnya bagi investor. EKUITAS (Jurnal Ekonomi dan Kenangan), 16(2), 164-183. https://doi.org/10.24034/i25485024.y2012.v16.i2.214

Putri, R. A., \& Isbanah, Y. (2020). Faktor-faktor yang memengarui keputusan investasi pada investor saham di Surabaya. Jurnal Ilmu Manajemen, 8(1), 197-209. Retrieved from https://jurnalmahasiswa.unesa.ac.id/index.php/jim/article/view/30746

Rakhmatulloh, D., \& Haryono, N. A. (2019). Pengaruh overconfidence, accounting information, dan behavioural motivation terhadap keputusan investasi di kota Surabaya. Jurnal Ilmu Manajemen (IIM), 7, 796-806. Retrieved from https://jurnalmahasiswa.unesa.ac.id/index.php/jim/article/view/29272 


\section{Fathmaningrum \& Utami}

Determinants of Investment Decisions in the Capital Market ...

Sakdiyah, H., Mahsuni, A. W., \& Mawardi, M. C. (2018). Pengaruh minat dan perilaku investor terhadap pilihan keputusan pada investasi beresiko. Jurnal Ilmiah Riset Akuntansi, 7(1), 101-112. Retrieved from http://riset.unisma.ac.id/index.php/ira/article/view/1338

Setiawan, Y. C., Atahau, A. D. R., \& Robiyanto, R. (2018). Cognitive dissonance bias, overconfidence bias dan herding bias dalam pengambilan keputusan investasi saham. AFRE (Accounting and Financial Review), 1(1), 17-25. https://doi.org/10.26905/afr.v1i1.1745

Sholihin, M., \& Ratmono, D. (2015). Analisis SEM-PLS dengan W ARP PLS 3.0. Yogyakarta: Andi.

Simões Vieira, E. F., \& Valente Pereira, M. S. (2015). Herding behaviour and sentiment: Evidence in a small European market. Revista de Contabilidad, 18(1), 78-86. https://doi.org/10.1016/i.rcsar.2014.06.003

Situmorang, M., Andreas, A., \& Natariasari, R. (2014). Pengaruh motivasi terhadap minat berprestasi di pasar modal dengan pemahaman investasi dan usia sebagai variabel moderat. Jurnal Online Mahasiswa (JOM) Bidang Ilmu Ekonomi, 1(2), 1-18. Retrieved from https://jom.unri.ac.id/index.php/JOMFEKON/article/view/4675

Somathilake, H. (2020). Factors influencing individual investment decisions in Colombo Stock Exchange. International Journal of Scientific and Research Publications (IJSRP), 10(5), 579-585. https://doi.org/10.29322/ijsrp.10.05.2020.p10166

Sukirno, S. (2011). Teori Pengantar Ekonomi Makro. Jakarta : Rajawali Press.

Sulistyowati, N. W. (2017). Pengaruh motivasi ekstrinsik dan prestasi belajar akuntansi terhadap minat investasi dan keputusan investasi mahasiswa FE program studi akuntansi UNESA. Jurnal Ekonomi Pendidikan dan Kewirausabaan, 3(1), 76-90. https://doi.org/10.26740/jepk.v3n1.p76-90

Sumtoro, A., \& Anastasia, N. (2015). Perilaku keuangan dalam pengambilan keputusan berinvestasi properti residensial di Surabaya. Finesta, 3(1), 41-45.

Suryani, T. (2013). Perilaku konsumen di era internet: Implikasinya pada strategi pemasaran. Graha Ilmu.

Tandio, T., \& Widanaputra, A. (2016). Pengaruh pelatihan pasar modal, return, persepsi risiko, gender, dan kemajuan teknologi pada minat investasi mahasiswa. E-Jurnal Akuntansi, 16(3), 2316-2341. Retrieved from https://ojs.unud.ac.id/index.php/Akuntansi/article/view/21199

Town, P. (2020). How to invest during pandemic. Rule on Investing. Retrieved from https://www.ruleoneinvesting.com/blog/how-to-invest/how-to-invest-duringpandemic/

Tversky, A., \& Kahneman, D. (1981). The framing of decisions and the psychology of choice. Science, 211(4481), 453-458. https://doi.org/10.1126/science.7455683

Umboh, J. E., \& Atahau, A. D. R. (2019). Investment Interest and Consumptive Behaviour of Student Investors: Between Rationality and Irrationality. Jurnal Dinamika Manajemen, 10(1), 14-31. https://doi.org/10.15294/jdm.v10i1.16837

Ummah, A., Ahsan, M., \& Anas, A. (2021). Students' investment decisions with intention as an intervening variable. Equilibrium: Jurnal Ekonomi Syariah, 9(1), 135-152. https://doi.org/10.21043/equilibrium.v9i1.9995

Vijaya, E. (2014). An empirical analysis of influential factors on investment behaviour of retail investors in Indian Stock Market: a behavioural perspective. International Journal in Management and Social Science, 2(12), 296-308. Retrieved from https: / $/$ www.indianjournals.com/ijor.Aspx?target $=$ ijor:ijmss\&volume $=2 \&$ issue $=12 \&$ article $=027$ 
Fathmaningrum \& Utami

Determinants of Investment Decisions in the Capital Market ...

Zaniarti, S., Ida, I., \& Novita, F. (2017). Perilaku investor galeri investasi BEI dengan AB Mitra Sinarmas Sekuritas Jawa Barat. MODUS - Jurnal Ekonomi dan Bisnis, 29(2), 176200. Retrieved from https://ojs.uajy.ac.id/index.php/modus/article/view/1330 